\title{
THREE CASES OF BILATERAL ACOUSTIC NEURINOMA
}

\author{
SHUJI KOTAKA, M.D, YASUSHI OKUBO, M.D., \\ YUJI ASE, M.D. AND ISAMU WATANABE, M.D. \\ Department of Otorhinolaryngology, Faculty of Medicine \\ Tokvo Medical and Dental University, Tokyo
}

(Director: I. Watanabe, M.D.)

Five cases of von Recklinghausen's disease were found in one family. In three of them, bilateral acoustic neurinoma were observed. The pure tone audiometry was performed repeatedly in two of them and the changes of audiograms were studied.

Clinical signs and symptoms of these cases seem quite different from those in unilateral acoustic neurinoma.

The changes in audiograms revealed the two periods in the progress of hearing loss. They were rapidly increasing periods and slowly increasing periods.

These results suggest the etiology of the bilateral acoustic neurinoma in von Recklinghausen's disease is different from other acoustic neurinoma.

A $80-0920-25222$

\section{両側聴衴経腫瘍を伴なったvon Recklinghausen 病の \\ 一家系について

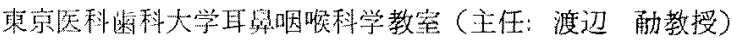

小高 修司・大久保上・液辺觔

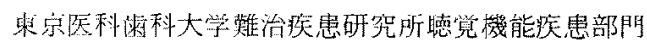

阿 䡩 雄 治

\section{I. 緒 言}

von Recklinghausen 病 (以下 $\mathrm{R}$ 病上路す)。の一家

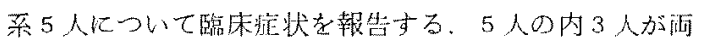
侧の德神経腫提 (Acoustic Tumor, 以下AT 上略す).

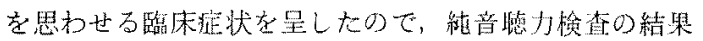
を主として臨床経過を述へ，興味する結果を得られたの で詳述し考察在加元る。更にATについて発生，病理学 的考察を加充て，道常の片側性のAT と雨側性 AT との

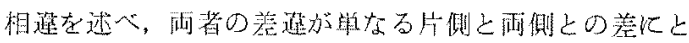
どまらす，むしら別の疾患と考えた力が良いのではない かとの侾えを述べる。

\section{2. 症例}

本家采の家柔図は图 1 の如くでり，各症例の下の数 字がこれ加ら述いる5人の䍐者の放例番号を示してい
3.

1. H. M. 男. 大正12年生

既往祭：特記すべき事なし。

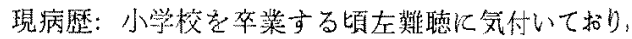
昭和 31 年 (33衤) 頭痛，めまいを主訴として某大学病院 老受診し， R 病の搒断受けている。37年11月(39藏)

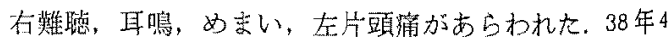
月両眼視力低下，うっ血秏嘼老指摘さ机九，以後上記定 状性渐時增覀し，38年 5 月本学第二外科を受彰した。

初診時所見：側頭骨レントゲン写真にて内耳道を中心 飞錐体骨の雨側の破擐像を綛如，睬血管造影飞上り椎骨 動脈の左方一の圧排像老認め大，脳神経注 V， UI, UII, X,

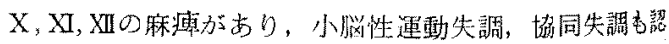

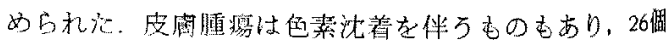




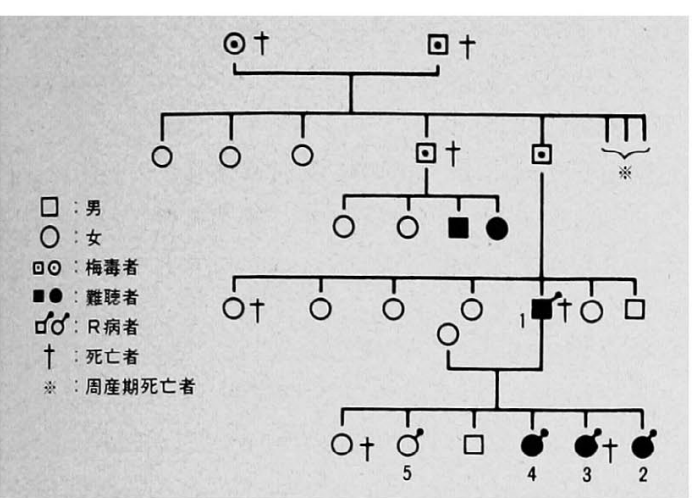

図 1 家 系困

(症例の下の数字は)

症例番号を表放し

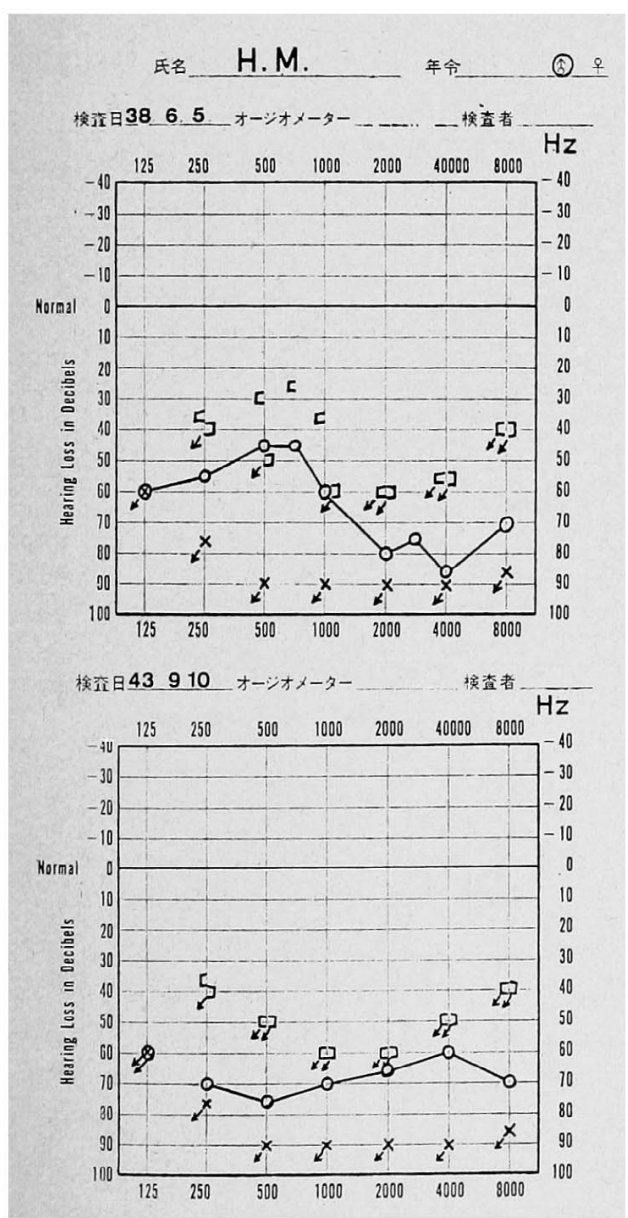

図 2 症例 1 の聴力像
‘あった．両側小脳橋角部腫痬の燮断の下K，38年 6 月後 頭下開頭法により手術を行なったが，腫瘍は線維性の性 状つよく, 深部血管系との結合屯つよく全摘出は不能で あり, 隇压術と左小脳の部分切除を行なった。術後経過 は良好であったが臨床諸症状の改善は少なかった。46年 3 月 (48 歳) 他院にて死亡した（直接死因不明）

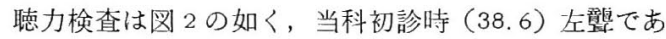
った. 約 5 年後の聴力検查では右の中低音部の難聴が進 行しているが, 通常のATに比べて, その進行は遅い.

2. S. M. 女. 昭和 22 年生

既往歴: 両側先天性白内障.

現病歴: 昭和 40 年 (18歳) 第 4 腰椎の高さの资䯣腫瘍 切除.この頃より歩行障害が現れた. 46 年皮咸腫瘍 5 個 切除して就り, この頃より時々両側の耳鳴（シー）が招 こるようになった，47年11月当科初診した。

初診時所見：脳神経症状に異常を認めず，軽度の左運 動失調，協同失調を認めたのみで，平衡障害も閉眼片脚 起立で動摇を示す程度でロンベルグも異常を認めなかっ た.

自発眼振は左方視に伴万左向大打性眼振を軽度認めた のみで、誘発眼振は出現しなかった，48年 7 月の来院時 自発眼振は図 3 の如く，いわゆる Bruns 眼振を思わせ るものであり，各種平衡機能検査の結果は下記の通りで あった. 即ち温度眼振検查は雨側水水 $20 \mathrm{ml} 10$ 秒間注水 に対して無反応であった。回転検查は暗所前屆頭位 $30^{\circ}$

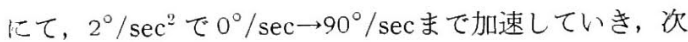
いで40秒間等速回転後急速停止を行ったが, 時計方向, 反時計方向共に回転中及び回転後の眼振解発は不良であ った，視標追跡検查は階段状波形を呈し，特に右一左一 メトロノーム型の視標が移動する時顕著であった．視運 動眼振検査は我々が独自に考案した一発刺激法装置によ り行なった。この装置及びこの装置によった各種検査結 果は今迄度々, 日本平衡神経科学会に於て発表及び投稿 しているので詳細は省略するが，基本的には Ohm 型の 刺激装置であり, 半径 $1 \mathrm{~m}$ 中心角60度の曲面を有する高 さ $1 \mathrm{~m}$ のスクリーンに, 暗所にて $3^{\circ} / \mathrm{sec}^{2}$ の角加速度で $0^{\circ} / \mathrm{sec} \rightarrow 120 \% / \mathrm{sec}$ と加速し, 次いで同加速度にて即刻 $120 \% \mathrm{sec} \rightarrow 0^{\circ} / \mathrm{sec}$ 迄減速していく光線条刺激を投影す る。刺激と眼反応 (眼振) との対応を明瞭飞把觉る事が できるように，光線条はスクリーン上に常に一本のみ現 れ，患者にはスクリーンの端から端まで追跡するよう に，又縞数を数える上万に指示，激励する。この一発刺 激法では刺激と眼反応とが 1.1 として把えられ，数的 
に観察できる為，刺激速度が早くなり追跡ができなくなり

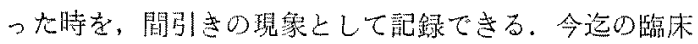

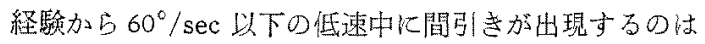
中枢神経系江障㫪存有する症例化多く, $90^{\circ} / \mathrm{sec}$ 位迄の 間に間引き现象加出る者蛙末梢前发系儿病变を有する可 能性加強く，正常者は間引きを認めないか，90\% $120^{\circ} / \mathrm{sec}$ の間に間引きが現机る事がわか⿰っている。本 症例の場合加速時は $75^{\circ} / \mathrm{sec}$ 位まで間引く事無く光刺激 を追跡しえるのに，堿速時は60\% $\mathrm{sec}$ 位になって濑く追 跡を再閥し，しかも多 slow phase は saceadic patternを

\section{Spontaneons \& Gaze nystagmus}
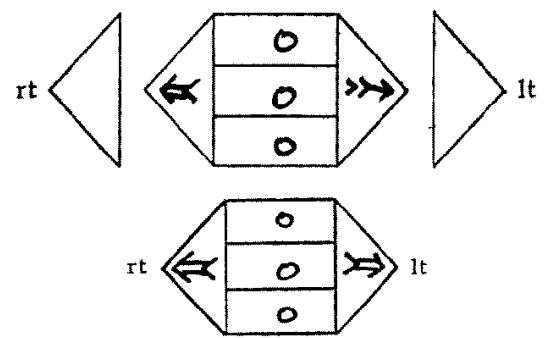

(behind spectacle)

\section{Positional test}

supine with head

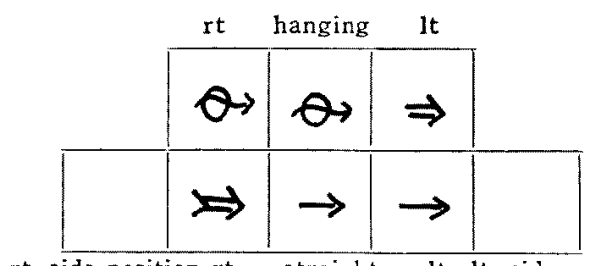

rt. side position rt straight lt lt. side position

\section{Positioning test}

supine with head
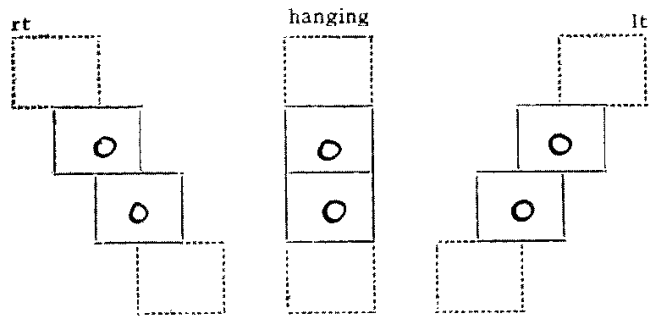

sitting with head straight

図 3 症例 2 の自発及び䅎発眼振
示して扣り，中枢障害型と判定した.

・平衡機能検查を経時的に行なっているが，その詳緗は 別の機会に発表したい上思う。

一純音蒿力検祖は初衫時及び最釉検査時のデータを图4

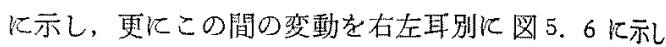
た.この所見及び解釈炕ついては考察の項で述へる事と する。

語音衈力桧查及び Tone decay test (図 7).57 式 ストを使用した語音㭘查の結果は純音聴力檢查加ら予想 された值より惡く，明嘹度は左 $84 \%$ 亿対し，右蛙 $58 \%$ を示している. Tone decay test は連続音刺激を10 間行なった時と断続音刺激との聴力の差をすって表し，

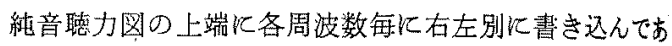
る. その值は0又は $5 \mathrm{~dB}$ といら事で Tone decay は陰 性であった.
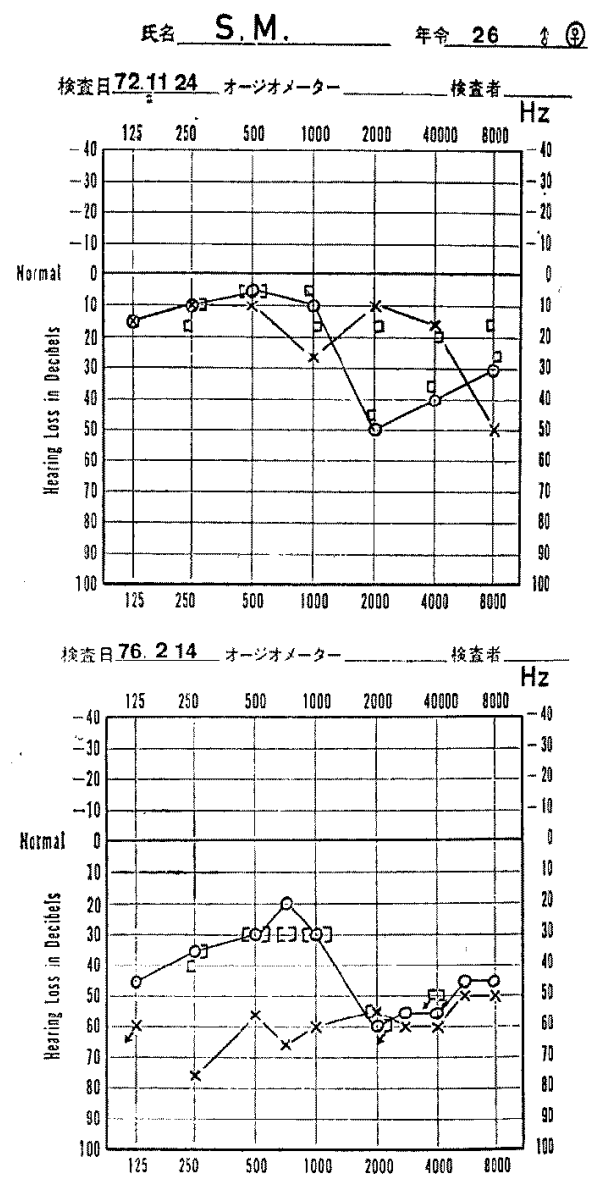

図 4 症例 2 の㴔力像. 初診時及最終検查時。 この間の变化が图 5 及 6 である。 


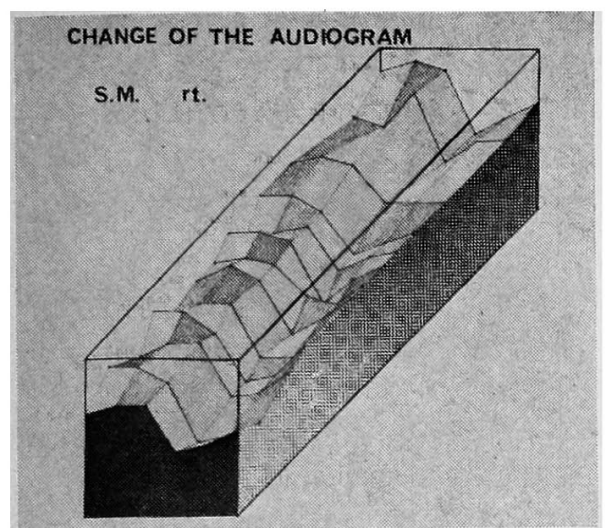

図 5 症例 2 の右耳純音聴力变化図 $\mathrm{X}$ 軸に各周波数, $\mathrm{Y}$ 軸に $\mathrm{dB}, \mathrm{Z}$ 軸に年月日を とってある. 傾斜角度の急な所はその検査期間 に難㯖の進行が速い事を示し, 緩い所は遅い事 を示している. 尚外枠 $\mathrm{X}$ 軸は $0 \mathrm{~dB}$ を示す $2,000 \mathrm{~Hz}$ K dip のある特異な形をしている.

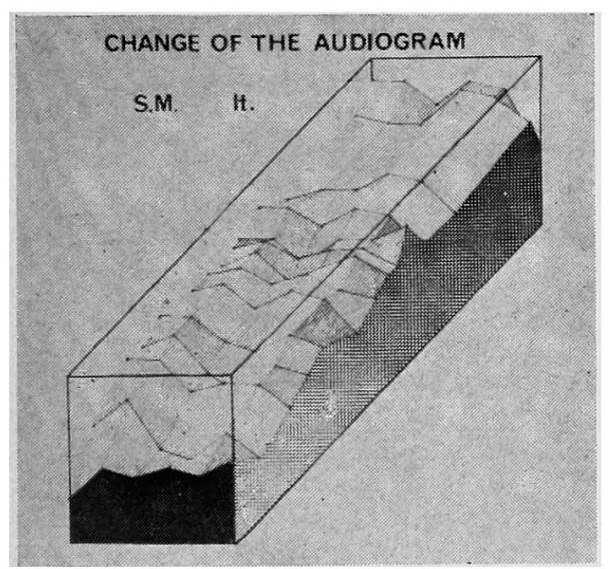

図 6 症例 2 の左耳純音聴力变化図

\section{T.M 女. 昭和 24 年生}

既往歴: 特記すべき事なし.

現病歴: 昭和38年 (14歳) 頃より左難聴を自営した. 40年頃より疲れると足が前に出せなくなり, 又この頃よ り食後 $1 \sim 2$ 時間すると嘔気嘔吐が起るようになった. 41 年 5 月頃より家人に料理の味付けが扔かしいと言われ ており，41年 8 月当院第二外科を受診した. 同年 9 月入 院時所見は右側腹壁等飞色素沈着を伴った小皮雐腫瘍が 散在しており, 脳神経症状は左 $V 、$ VII, 汭の麻瘏を認め, adiadochokinese が認められたが，脳冾䯣圧は正常で, 液の性状にも異常を認めなかった。側頭骨レントゲン写

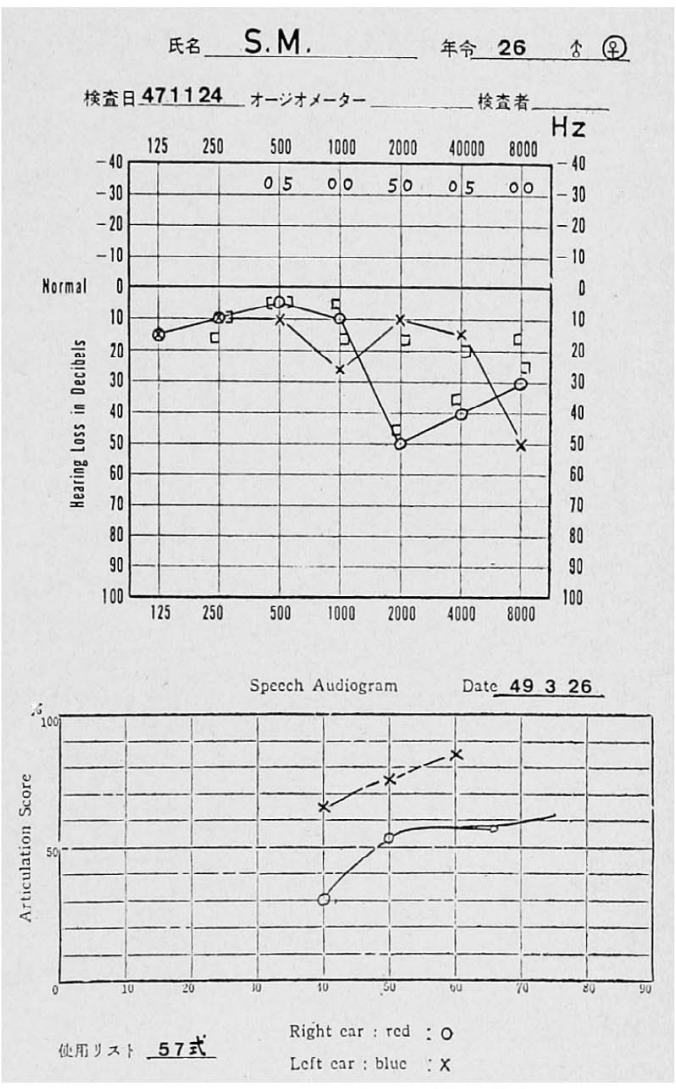

図 7 症例 2 の純音聴力之語音聴力図. 明睹度曲線を示す。各周波数 $(500 \sim 8,000 \mathrm{~Hz})$ の下の数字は Tone decay test の值を示し, 向 って右が左耳, 左が右耳の結果である.

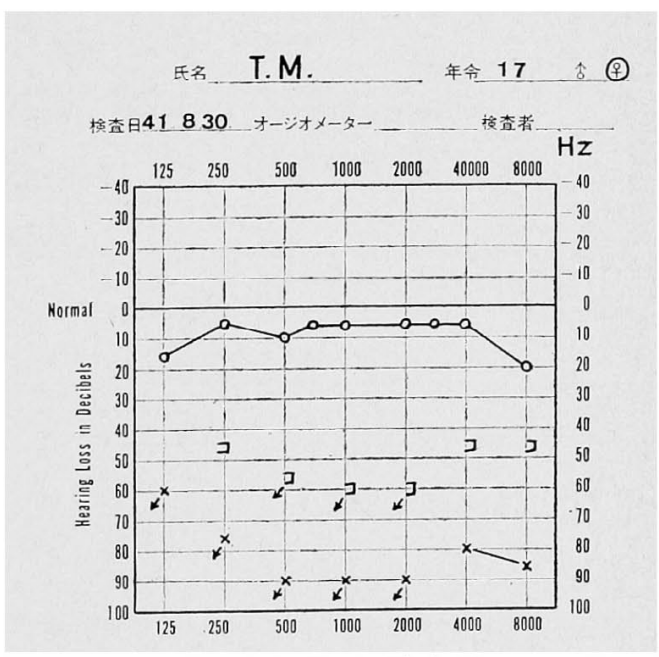

図 8 症例 3 の恥力図 


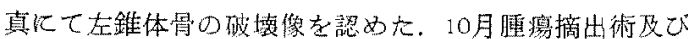

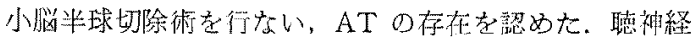
は霾淇の腹側にあり，一部腫㨽に包まれたようになり，

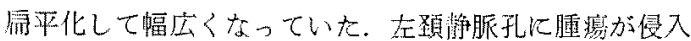

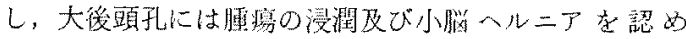

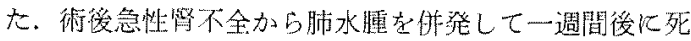
亡した。

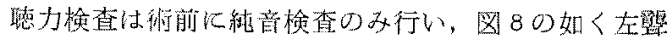
であったが，右块正常であった。

\section{Y.M. 女. 昭和25年生.}

咋往歷: 特記ずベき事存し。

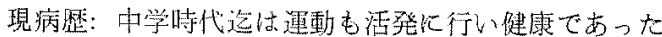

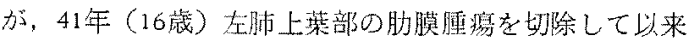
連動をしなくなった。46年と48年に瞬間的な意識畩失発
作が些行中にあったが，较倒はしなかった，蜩牛症状の 随判は認めなかった。 48年夏比より他人に難聽を指捝さ れ，10月頃より自筧的にも雑㯖飞気付いた，11月上り耳

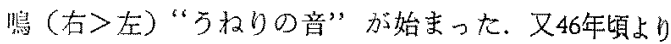
速く歩く事ができなくなっていた．49年3月当科受診し

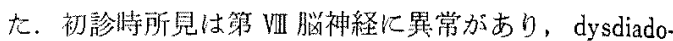
chokinesia を热めたが，頝動眽及び椎胃動脈造影では明 らかな筫常所胃を諗めなかった，側頭骨レントゲンにて

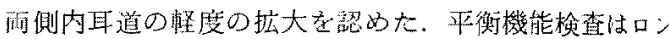
ベルグは階性であり，片脚起立不能 (左への転制傾问) で，足䠌検查は staggering が強く殆んど不能であった

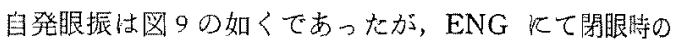
记録克行なうと，いわゆる Bruns 眼振を認的た。温度 眼振梌查は水水 $20 \mathrm{ml} 10$ 秒間注水儿て雨測無反応であ

\section{Spontaneons \& Gaze nystagmns}
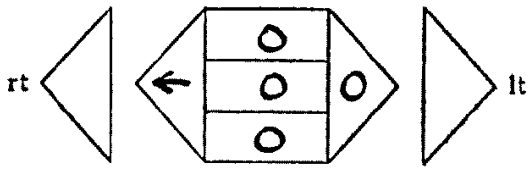

Positional test

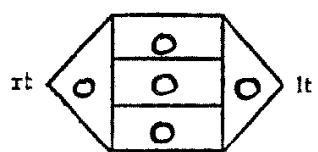

(behind spectacle) supine with head

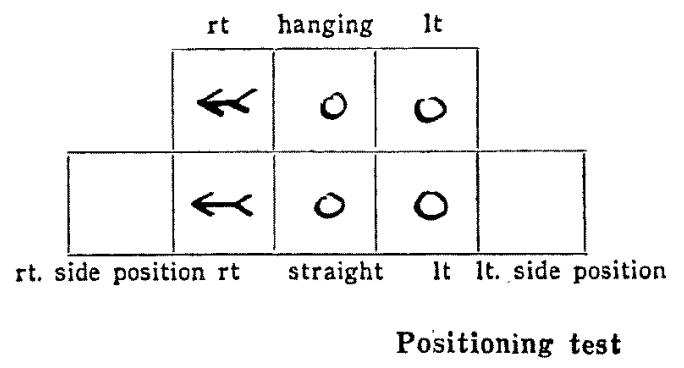

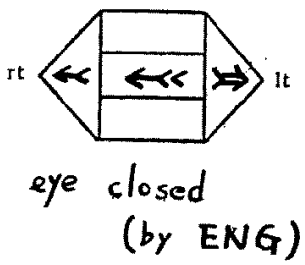

(by ENG)
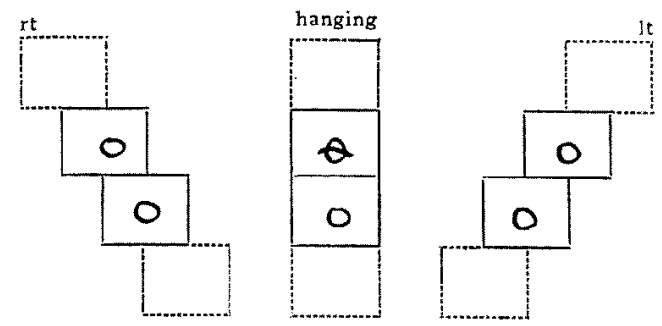

sitting with head straight

図 9 症例40自発及び誘発眼振 
り, 回転検查は回転中右 DP 傾向を認めたが, 回転後眼 振の解発は全く不良であった. 視標追跡検查はわつが

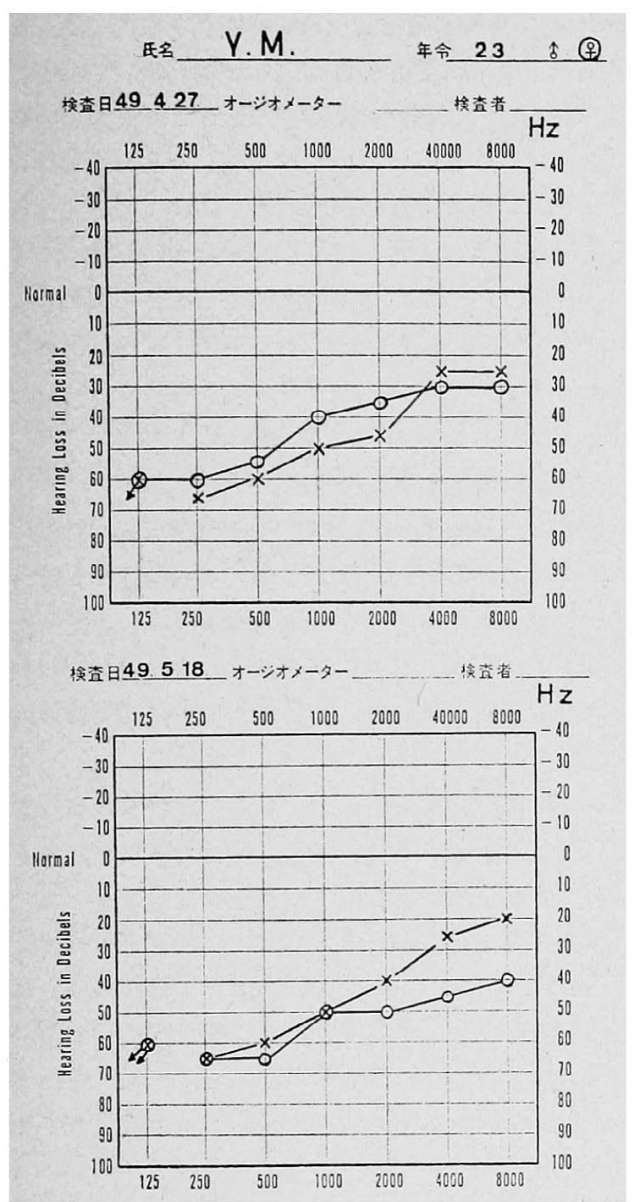

図10 症例 4 の㯖力図. 初診時及び鼠終検查時.

この間の変化が図 11 及び 12 である。

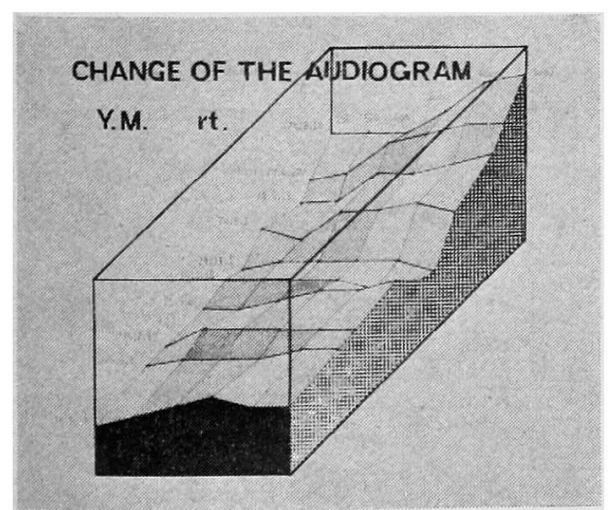

図11 症例 4 の右耳純音聴力变化図 saccadic pattern を示し，視運動眼振検査では $75^{\circ} / \mathrm{sec}$ 位で間引きを認めたが, 経時的に行なった結果, 徐々に 低速度で破綻を来たすようになり中枢障害型となってい った．詳細は別の機会汇発表するつもりである，純音聴 力検査は症例 2 上同様に初診時上最終検査時の結果を図

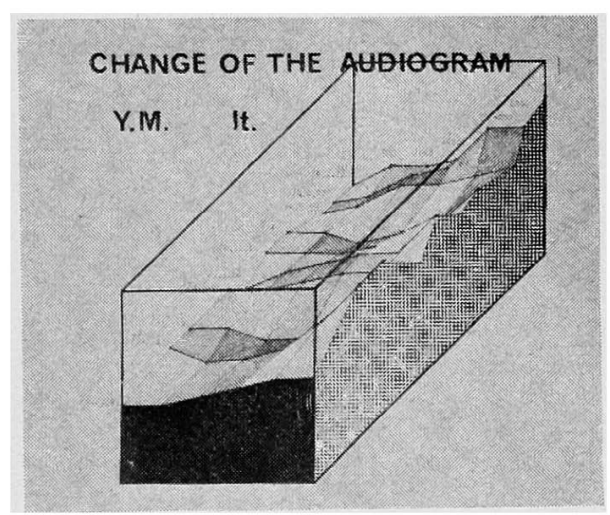

図12 症例 4 の左耳純音聴力变化図

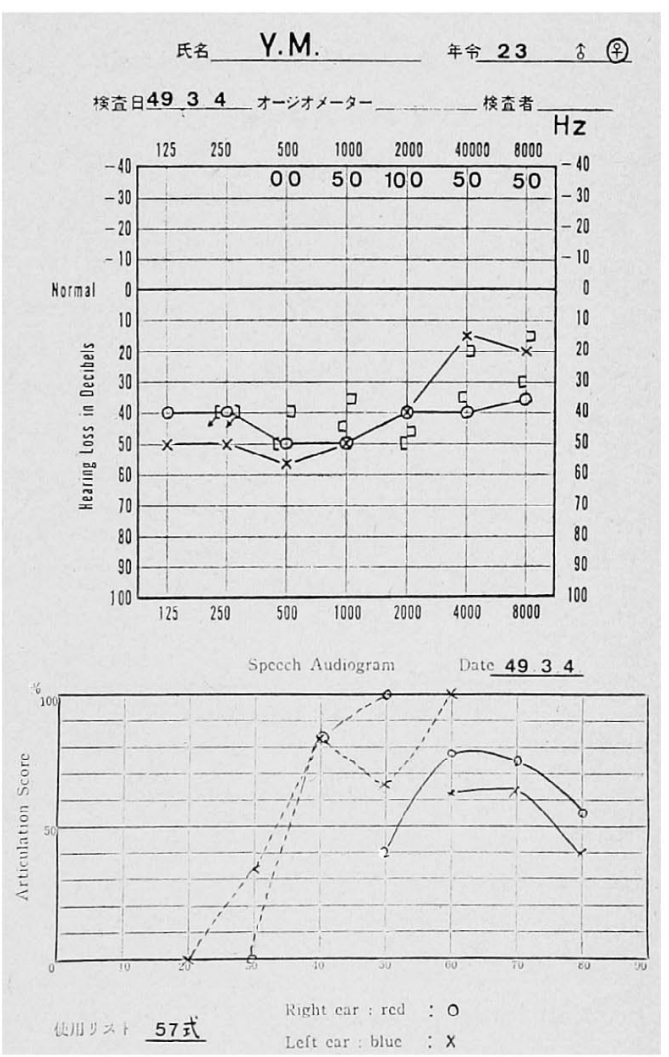

図13 症例 4 の純音㯖力検查と語音媤力検盉図 破線はSRT. 実線は明瞭度曲線を示している。 


\section{Spontaneous \& Gaze nystagmus}
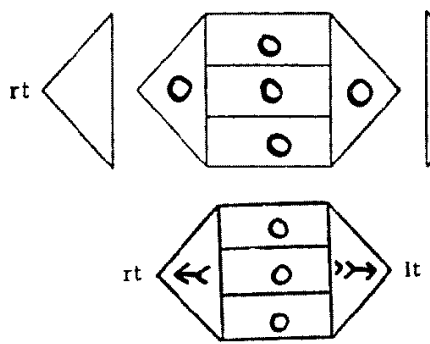

(behind spectacle)

\section{Positional test}

supine with head

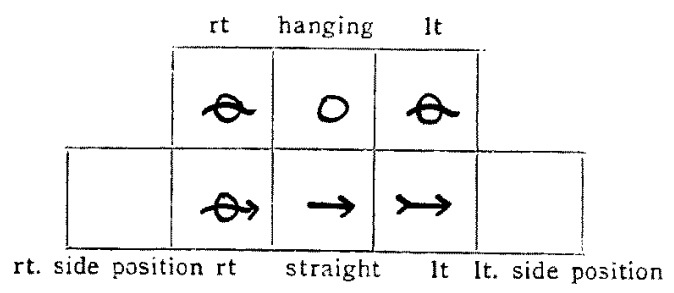

Positioning test

supine with head
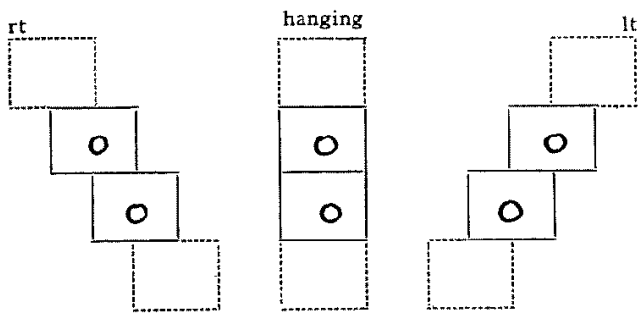

sitting with head straight

図14 症例 5 の自発及び誘発眼振
10 K示し，その間の变動を三次元の図で 11，12 飞描い た，詳細については考察の項で述べる．図13亿語音聴力 检查及び Tone decay test の結果を示してあるが，破 線で示したの洁語音聴取域值 (SRT) である，通常 STR の $50 \%$ 偲が $\pm 5 \mathrm{~dB}$ で純音平均浐力と相関する上いわれ ている阮，本症例ては純羙平均聴力值より良い值を示し ている，又純音検查では左右差を認的ないても拘らず， 語音明䐲度は左の低下を示して和り與味がもたれる。 Tone decay test の結果は症例 2 と同様化記载してある が，本症例犯於ても陰性である，尚，耳内筋反射怯正常 であった。

\section{M.S 女. 昭和 35 年生}

既往歴：特記すべき事なし。

現病歷: 46年 (11歳) 腰椎上の皮苚腫瘍 2 個切除した。 49年 5 月当科受部. 初㟝時の所見は脳神経化異常所見を 認めずわづが右の dysdiadochokinesia を認めた。 口 ンペルグは正常であったが，Mann では閒閉眼時共に左

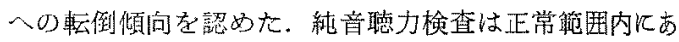
った。

自発眼振は図14亿記した，温度眼振検查は右 $\mathrm{CP}+$ 左 $\mathrm{DP}$ であったが， $44^{\circ} \mathrm{C}$ の温水刺激て眼振が解発さ机て いるに类拘らず，回転めまい感を伴なわなかった，視標 道跡榆肾は正常の波形を示したが，視運動眼振検亘は左 右共化減速時 $75^{\circ} / \mathrm{sec}$ 迄間引きが多く破綻傾向を示し， 末梢型障害定呈した．回轱娭查は回転中，後共化眼振の 解発が正常者にくらべてやや悪い傾向にあった。

以上 5 症例の臨床症状を一覧表化して表 1 火まと好 みた。

3. 考 察

1. 発生及び病因

内耳正び䐉神経の発生は初め anditory vesicle の内則

R. 病一家系の蹦枺症状

\begin{tabular}{|c|c|c|c|c|c|c|c|c|}
\hline & 初発症状 & 初発年龄 & 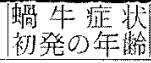 & 難 㯖 & 脳神経症状 & 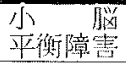 & 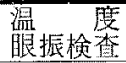 & その他 \\
\hline 父 & 左 難 呫 & 12 & 12 & 両 & + & + & & 49歳死亡 \\
\hline 長 女 & 步和障羖 & 18 & 24 & 两 & + & + & 㮪反応 & \\
\hline 次 女 & 左 嚾 渞 & 14 & 14 & 左のみ & + & + & & 12葴死亡 \\
\hline 三女 & 灾神登作 & 21 & 23 & 雨 & + & + & 梨 反応 & \\
\hline 四女 & 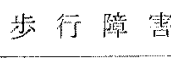 & 15 & 末 & 未 & 無 & \pm & $\begin{array}{l}\text { r.-CP } \\
\text { l.-DP }\end{array}$ & \\
\hline
\end{tabular}

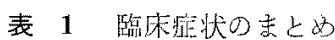

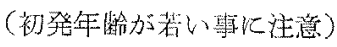


及び腹側に位置する acousticofacial ganglion として知 られて拈り，次いてこれから facial portion 加分加机， 梳いて vestibular ganglia 2 cochlear ganglia

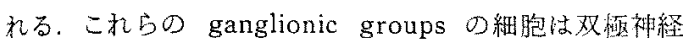
節細胞になるものと，神経䩪の neurilemmal cells 己K 分かれる，双極細胞は一力の軸索を auditory vesicle 一 延ばし，他方で脂幹へ上延びる。これは䀲神経の前庭及 び螖牛部の頭蓋内部老形作る為である，双極綢胞の線維 茫 neurilemmal cells の線維と共化（数は双極細胞の 線維が多い)脳翰に向って延びていき, 脳幹汇垚すると glia 細胞加らの線維肪末梢に向って延び始める。前庭神

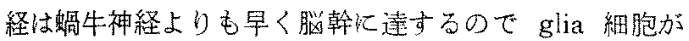
遊走を始めるの毛前庭神経の力が早い。

以上の発生学的基盤飞よりATの発生を考充てみる。 Verocay ${ }^{12}$ は神経内の胎生組織の透残加 AT の因である と述へている，成人男子の㯖神経の長さは約 $17 \sim 19 \mathrm{~mm}$ であり, glia 部と non-glia 部の二つにはっきり分れて いる. glia 部は脳幹部から $10 \sim 13 \mathrm{~mm}$ の所运で, 内耳 道のレベルで non-glia 部につながっている, non-glia

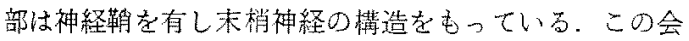
合部での鞋細胞の配列の乱れと過剩开成は蝸牛神経節上 り前庭神経節に明らかに認められる。故に AT は前庭 神経の内耳道内の non-glia 部の神経鞘細胞加b発生与

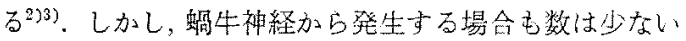
があるという ${ }^{17}$ 、いつれにせよATが内耳道の末梢部に

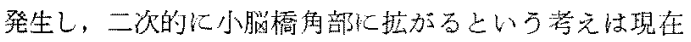
広く受け入れられているが，1915年 Henschen²がこの 説を発表する以前はATは小絪橋角部より発生し，时に

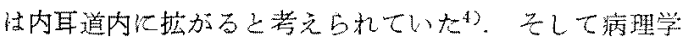
的化 ATが神経䩗細胞から発生すると証明された が，

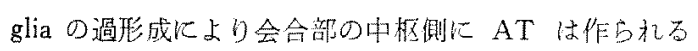
との説もある202

$\mathrm{R}$ 病の発生病㻎を考光る。神経線維腫の起原に閶して は Virchow (1863) 以来多くの諭誘加為されて扣り，新

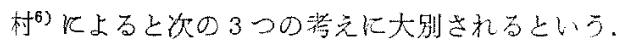

1) 外阫葉性, Schwann 細胞由来説

2) 閶葉性結合織的来説

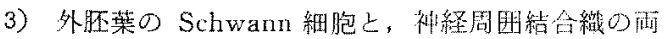
者们由来する上する説

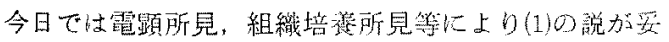
当とされている。

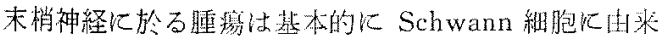
する神経蝺腫上Schwann 細胞上 endoneural fibroblast

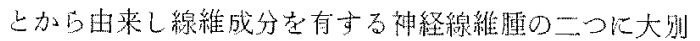

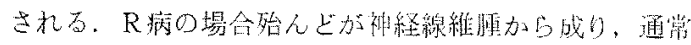

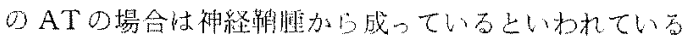

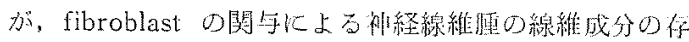

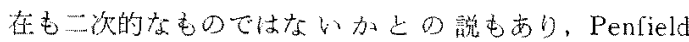

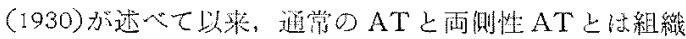

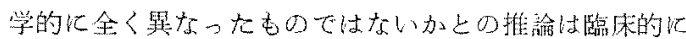

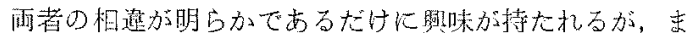

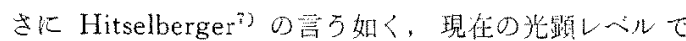

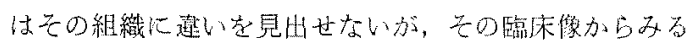
腫境の態度の邆いは明らかでり，発生のbasic cellに

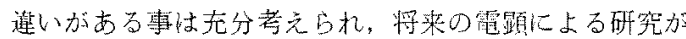
待たれる。

Cushing はその大著の病因と頻度 (第 5 章) ${ }^{8)}$ の結覦 上して次のように述心ている。 AT は神経の末梢終末の

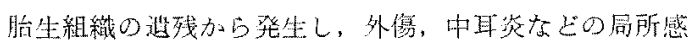
染，妅娠が增㽝の引金上なる。

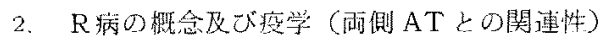

R病の主要徵候はいるい万とあげられているが次の起

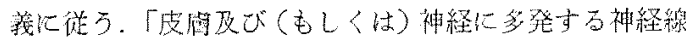

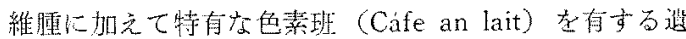
伝性门疾患」9?.

$\mathrm{R}$ 病の発生頻度は䄪 3,000 人に1人の判含て性差あり

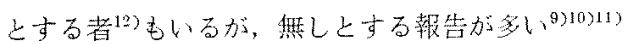

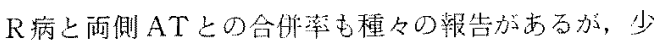
く共50\%以上の高染で方古。全ATの内, 雨侧ATの頻

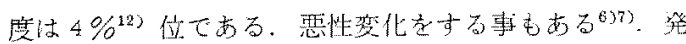

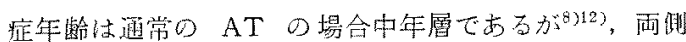
AT の場合 Gardner ${ }^{133}$ がメンデルの法則に即った一家

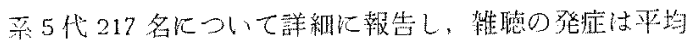

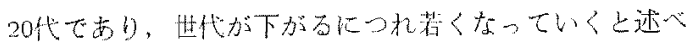

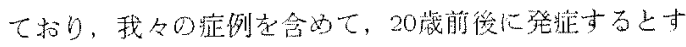
方報告は多(14)17>18，

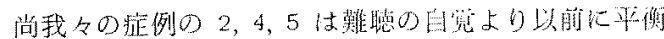

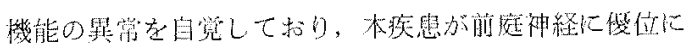

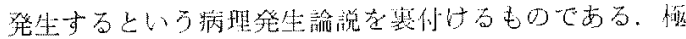

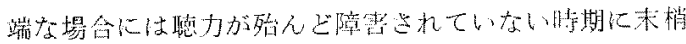
前庭が破綻している例もある゙、しかし山牌蜼聴などの

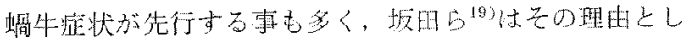

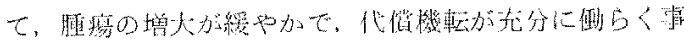

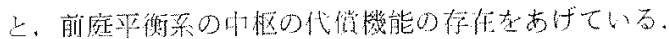

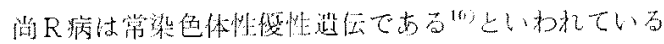

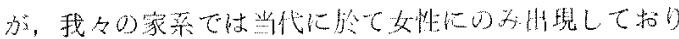




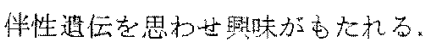

3. 臨床症状について

R病である票を確諗しえた一家系 5 人について臨床症 状を述べた。特に症例 2 上 4 は長期間に渡り恥力检查攻

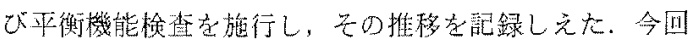

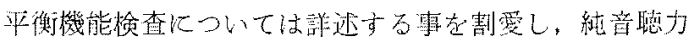

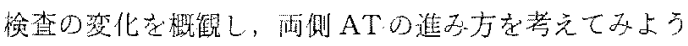
七思う。

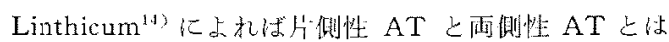

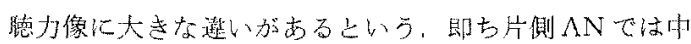

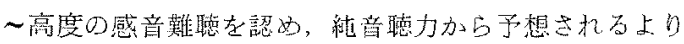

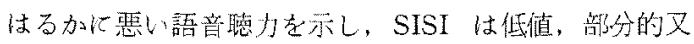

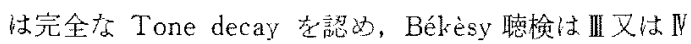

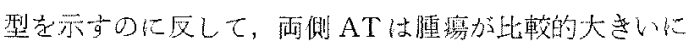

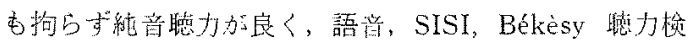

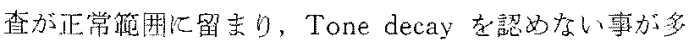

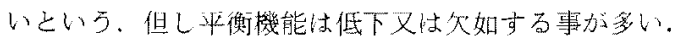

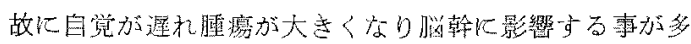

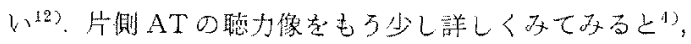

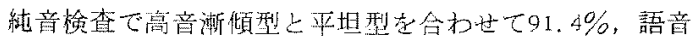
性查で0 30\%の者が $68.9 \%$, Békèsy III, VI型の著が

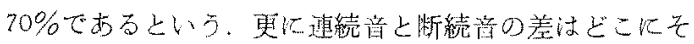
の差があるか上り，差の大きさが上り重要な意味をもっ て扣り，故にATを梌索するには先ず Tone decay test をスクリーニングとして行ない，先机異常の出た者长

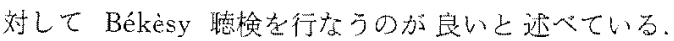
我々の在例の場台 Tone decay t哂めず Nager ゃ

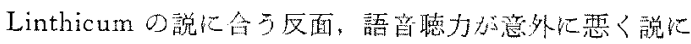

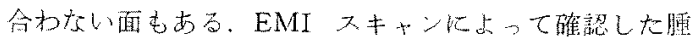

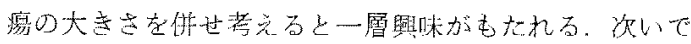

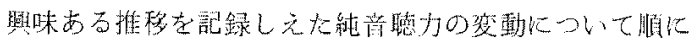
述バてる。

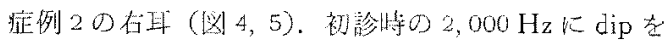

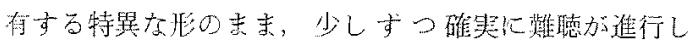

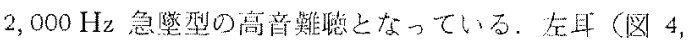

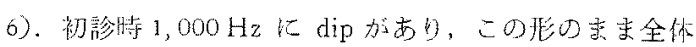

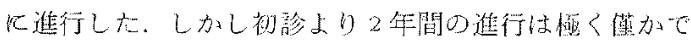

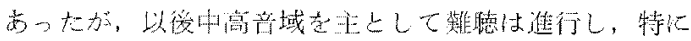

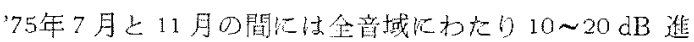

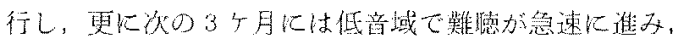

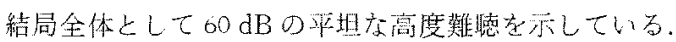

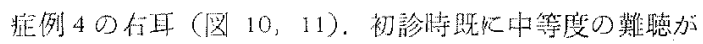

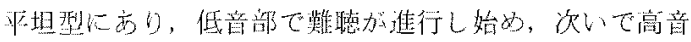

部が進み，結局再び平坦型難聴とふった. しかし'74年

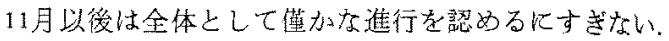

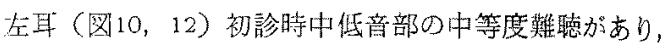
初めは右耳之同様に低音部で颗聴が進行し，次いで中音 域吕瑟化し，次に 4,000 Hz，最近になって $8,000 \mathrm{~Hz}$ が

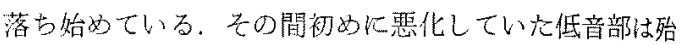
九立变化していない。

以上の様に音域により奞㯖進行の街期がズレている事

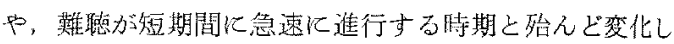

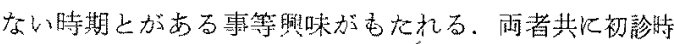

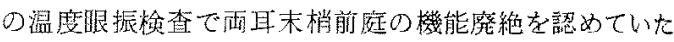
事上考之合わ甘る上，この变動は一層舆味泳いものがあ

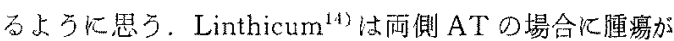

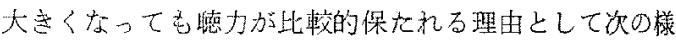
に述ヘている。片測 ATO埸合は前庭神経加発生し堌 大した腫㾇は，前庭神経，蛤牛神経艺押しのけ，あ大か もカブセルのまわりに稆経がばりついているかの如く 見えるのに対して，両側ATの場合々腫瘍はより浸潤性

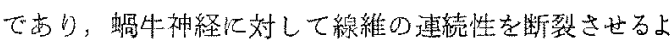
万に作用せすを，一本一本の線維をバラバラにはぐすよ うに作用するからである。

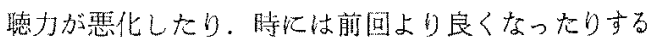

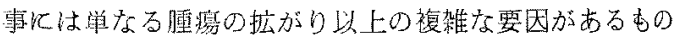
と䍐われる。大久保ら ${ }^{15}$ が述べている上うな腫瘍の進展 力向のヘクトル成分としてのエネルギ一や血篦系への影

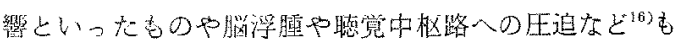

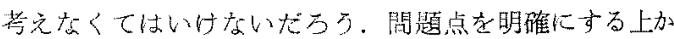
らこれらの要因圭取り除いて単に腫汪の拡がりといった

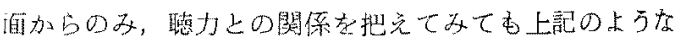
闍題吕生じてくる。

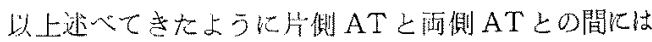

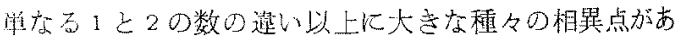

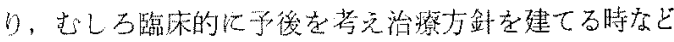
别の疾患として把无て招いた力が良いのではないかと考

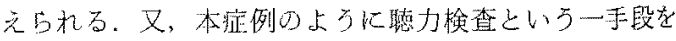

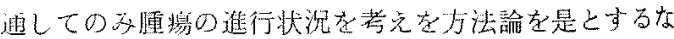

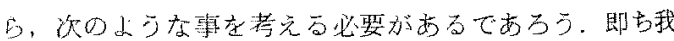

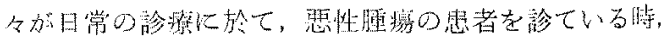

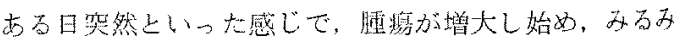

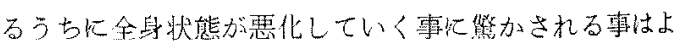

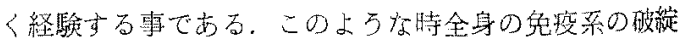
といった事汃原网なのだるうかと考光を巡すが、これと

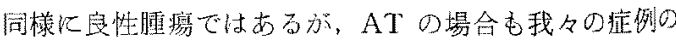




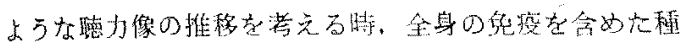
々の関与を看過す事が然いように注琶与べきてあるう。

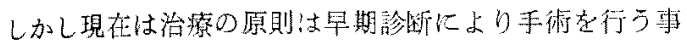

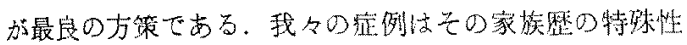

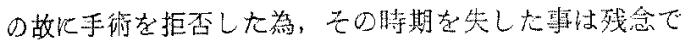
あったが,この故にATの長期短祭デー夕在得ら机た。

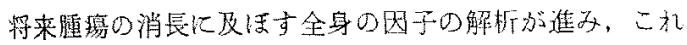

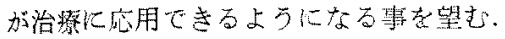

\section{4. 結 論}

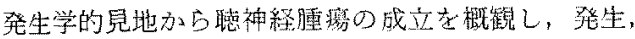

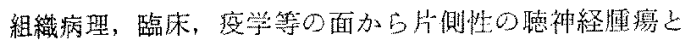

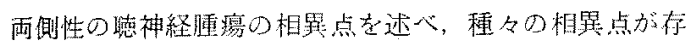
在する事上り，舟者走別の疾息と理解し刘処する方方よ

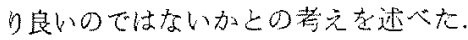

我々が経験した雨則聴神経腄幏妾有するフナン・レク リングハウゼン病の一家系の内，2名てつき恥力検查攻

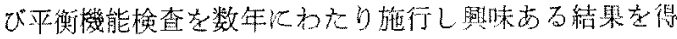

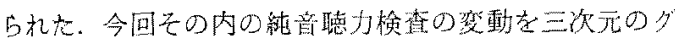

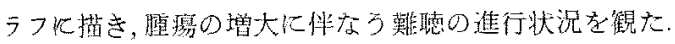

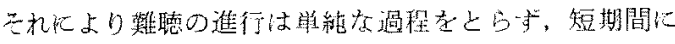
速やか心增瑟する時期と殆んど進行しない時撕上がある

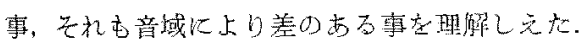

\section{文献}

1) Verocay, J.: Zur Kenntnis der "Neurofibrome." Beitr. Path. Anat. 48; 1-68, 1910.

2) Henschen, F.: Zur Histologie und Pathogenese der Kleinhirnbruckenwinkeltumoren. Arch. Psychiat. 56; 21-122, 1915.

3) Skinner, H.A.. Origin of Acoustic Nerve Tumors. Brit. J. Surg. I6; 440-463, 1929.

4) House, W.F.: Monograph Transtemporal Bone Microsurgical Removal of Acoustic Neuromas. Arch. Otolaryng. 80; 597-750, 1964.

5) Stout, A.P.: Tumors of the Peripheral Nervous System. A,F,I.P. Atlas of Tumor Pathol. 11; $6,1949$.

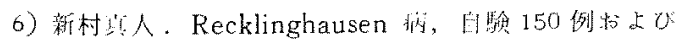

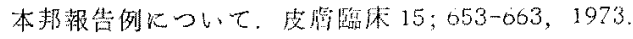

7) Hitselberger, W.E.: Bilateral Acoustic Tumors and Neurofibromatosis. Arch. Otolaryng. 88; 700-711, 1968.

8) Cushing: Tumors of the Nervus Acusticus 147-
151. Philadelphia. W.B. Saunders Co. 1917.

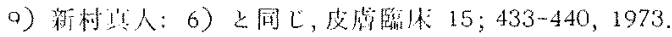

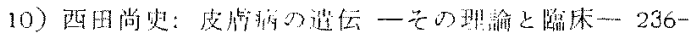

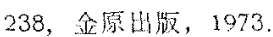

11) Rook et al: Textbook of Dermatology Vol. 1. 48-50, Blackwell, 1968.

12) Nager, G.T.: Acoustic Neurinomas. Arch. Otolaryng. 89; 252-279, 1969.

13) Gardner, W.J.: Bilateral Acoustic Neurofibro mas. Arch. Neurol, \& Psychiat. 23; 266-302, 1930.

14) Linthicum, F.H.: Unusual Audiometric and Histologic Findings in Bilateral Acoustic Neurinomas. Arch. Otolaryng. 81; 433-43?, 1972.

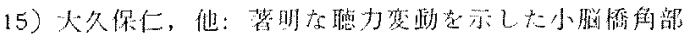
獾暗の 2 耀例. Audiology (Japan) 18; 112-116, 1975.

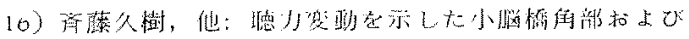

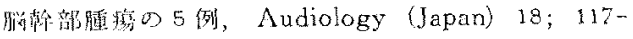
$122,1925$.

17) Nager, G.T.: Association of Bilateral Nerve Tumors with Meningiomas in von Recklinghausen's Disease. Laryngoscope 74; 1220-1261, 1965.

18) Edwards, C.H. et al: A Review of the Symptoms and Signs of Acoustic Neurofibromata. Brain 24; 144-190, 1951

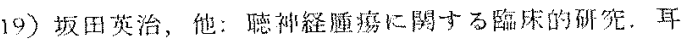

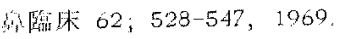

20) Worster-Drought, $C$. Multiple Meningeal and Perineural Tumours with Analogous Changes in the Glia and Ependyma. Brain 60; 85-117, 1937.

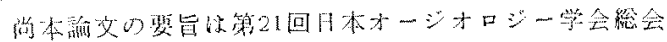
比程起上。

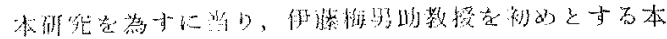

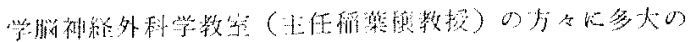

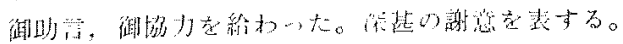

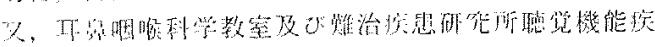

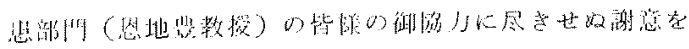
步- 万o

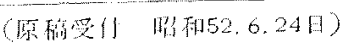

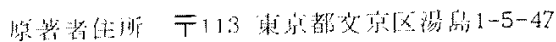

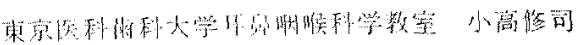

